\title{
Hg in petroleum systems and sulfide: are we missing the real anomalies?
}

\author{
HOLly J. STEIN ${ }^{1,2}$, JUDith L. HANNAH ${ }^{1,2}$ \\ ${ }^{1}$ AIRIE Program, Colorado State University, Fort Collins, \\ Colorado 80523-1482, USA (*correspondence: \\ holly.stein@colostate.edu) \\ ${ }^{2}$ Geosciences, University of Oslo, 0316 Oslo, Norway
}

In the past decade an enormous and enthusiasic effort has gone into defining and refining $\mathrm{Hg}$ anomalies in association with earth crisis events, notably the Permo-Triassic extinction ${ }^{[1,2]}$, Toarcian $\mathrm{OAE}^{[3]}$, and Eocene PETM ${ }^{[4]}$. Mercury concentration and to a lesser extent $\mathrm{Hg}$ isotopic data have been used to conclude that volcanic emissions, fly ash, and euxinic conditions in the sedimentary environment were responsible for $\mathrm{Hg}$ excursions in the geologic record.

Here we present new $\mathrm{Hg}$ concentration data from core samples of Upper Jurassic, Kimmerigian-equivalent black shales in the North Sea. Unlike the UK Kimmeridgian section that has been used as a normalization interval for $\mathrm{Hg}$ studies of Lower Jurassic shales ${ }^{[3]}$, we find a wide range of $\mathrm{Hg}$ concentrations, many of them among the highest measured ( $>2000 \mathrm{ppb})$. Further, we documented and analyzed several varieties of bedded pyrite nodules, some markedly less and some dramatically higher in $\mathrm{Hg}$ than their immediately hosting shale counterpart. Some cores presented oil and bitumen which were analyzed, and leaching of residual oil in a reservoir play produced mundane $\mathrm{Hg}$ concentrations. Our data show variation at the stratigraphic level that exceeds any varariations measured to date. The variations observed do not necessqrily correlate with TOC, degree of maturity, or other RockEval parameters. We are presently coupling these data with Os isotopic data, and suspect external intervention beyond local pore fluids.

Lessons learned and to be further explored are (1) the source and mobility of $\mathrm{Hg}$ in the geologic record is likely far more complicated than present studies might indicate, and (2) modeling $\mathrm{Hg}$ cycling, $\mathrm{Hg}$ reservoirs, and $\mathrm{Hg}$ 's elusive behavior requires understanding another large $\mathrm{Hg}$ reservoir on planet earth: petroleum systems. Consider the injection of $\mathrm{Hg}$ into seawater through degassing of methane from the seabed, or the explusion of deep marine tar balls that float around continents before arriving on welcoming shoreline ${ }^{[5]}$. Chasing $\mathrm{Hg}$ from source to sink has been a challenging but enlightening undertaking. Data from petroleum systems must be incorporated into discussions on $\mathrm{Hg}$ cycling.

[1] Grasby et al (2017) Geology 45: 55-58; [2] Shen et al (2019) Geology 47: 117-121; [3] Percival et al (2015) EPSL 428: 267-280; [4] Jones et al (2019) Clim Past 15: 217-236; [5] Scarlett et al (2019) Org Geochem 133: 77-91. 